\title{
Staying on the Farm: \\ Surviving the Great Depression in an Iowa Township, 1920-1950
}

\section{FRANK YODER}

FEW EVENTS have affected the rural Midwest as dramatically as did the Great Depression. During the 1930s economic, social, and natural changes tore into the fabric of life in many areas. By 1939, mortgage and insurance companies, banks, and other lending agencies held nearly 30 percent of the farmland in Decatur and Wayne counties in southern Iowa as farmers defaulted on mortgage payments. ${ }^{1}$ As early as 1933 , violence had erupted in Plymouth County as farmers nearly killed a judge for allowing foreclosures to continue. ${ }^{2}$ Parts of Kansas literally blew away as winds tore at the parched, grassless soil, reducing some areas of the state to desert. ${ }^{3}$ In the eyes of some, the nation stood on the brink of wrenching, violent economic change; for others it was nature's armageddon worsened by the economic despair that gripped the nation.

Yet the dramatic events that evoke such graphic images of rural life during the depression do not reflect the entire reality. Standard histories of the depression emphasize political and economic changes or focus on the radicalism and violence that characterized some areas. ${ }^{4}$ The rapid growth of New Deal pro-

1. William Murray, Corporate Land, Foreclosures, Mortgage Debt and Land Values in Iowa, 1939, Iowa Agricultural Experiment Station (IAES) Research Bulletin 266 (1939), 311.

2. John L. Shover, Cornbelt Rebellion: The Farmers' Holiday Association (Urbana, IL, 1965), 114-25.

3. Donald Worster, Dust Bowl: The Southern Plains in the 1930s (Oxford, 1979).

4. Examples of Iowa agricultural history include Earle D. Ross, Iowa Agriculture: An Historical Survey (Iowa City, 1951) as well as Shover's Cornbelt Rebellion. Ross's history is the latest comprehensive history, but recently pubTHE ANNALS OF IOWA 51 (Summer 1991). (C) The State Historical Society of Iowa, 1991. 
grams, the economic upheaval of farm foreclosures, and the accompanying farmer protests have always attracted the attention of both scholars and the popular press. ${ }^{5}$ In a period when increased corporate land holdings appeared to threaten traditional ownership patterns, the resiliency of rural communities remains largely unexamined. As a result, it becomes easy to assume that all rural areas experienced radical social and economic upheaval, when such disruption was, in fact, quite uneven.

This study examines the effect of collapsing real estate values on family farm ownership in one Iowa township in southeastern Johnson County prior to, during, and following the Great Depression. For most who lived in Lincoln Township during those years, it was a time of quiet struggle. The vast majority did not lose their land, though most probably felt very vulnerable in a time of extremely low commodity prices, falling land values, bank failures, and a chronic cash shortage. It was also a paradoxical period, as debt and falling prices overwhelmed some farmers while opening doors of opportunity for others. For those who lost their land, change was inevitable and somewhat predictable. For the few with substantial assets, the depression made extraordinary growth a possibility. But for most, it was a time when all available resources were utilized simply to survive with their land intact. Within certain limits, kinship structures and changing patterns of land transfer were the keys to survival. Familial links proved a very viable and effective framework within which farm families devised tenure

lished articles include Leland Sage, "Rural Iowa in the 1920s and 1930s: Roots of the Farm Depression," Annals of Iowa 47 (1983), 91-103; Dorothy Schwieder, "Rural Iowa in the 1920s: Conflict and Community," ibid., 10415; Joseph F. Wall, "The Iowa Farmer in Crisis, 1920-1936," ibid., 116-27. Understandably, the role played by Henry Wallace during this time has always received a great deal of attention as the remaining articles of the Fall 1983 issue of the Annals illustrate. For a more rounded portrayal of Iowa farm life during the depression, see H. Roger Grant and L. Edward Purcell, eds., Years of Struggle: The Farm Diary of Elmer G. Powers (Ames, 1976).

5. An illustration can be found in Patricia Dawson and David Hudson, Iowa History and Culture: A Bibliography of Materials Published Between 1952 and 1986 (Ames, 1989). The section on agricultural unrest contains thirty-five references dealing with the Great Depression. 
and transfer strategies aimed at protecting their land during a period of severe economic decline.

LINCOLN TOWNSHIP exhibits many characteristics of a prosperous farming community. Its twenty-four square miles of gently rolling land include some of the better soil types in the area and in the state. ${ }^{6}$ Even though high soil quality has been linked to economic well-being, land and commodity prices in Lincoln Township reflected the general decline found throughout the Midwest after World War I, a decline that was followed by a more precipitous plunge during the depression. Although land values in Lincoln Township remained at higher levels than the state's average, they fluctuated along with statewide prices throughout the period. ${ }^{7}$ Recorded prices for land in Lincoln Township averaged $\$ 331$ per acre in 1920 , with a peak price of $\$ 537$ per acre paid for a forty-acre tract in that same year. By 1925 , the average price had declined to $\$ 221$ per acre, and by 1935 it had fallen to $\$ 120$ per acre, with a low of $\$ 94$ per acre paid in $1936 .^{8}$

6. With the exception of the open streams, virtually all the soil types present in Lincoln Township are classified as prime farmland soils. See U.S. Department of Agriculture (USDA), Soil Survey of Johnson County (1983), 88-91 and sheet numbers $70,77,84$.

7. H. Wayne Bitting, "Farm Foreclosures in Southern Iowa from 1915 to 1936 in Relation to Land Values, Type of Mortgage Holder, and Soil Erosion" (Master's thesis, Iowa State University, 1937); Lowell Dyson, "Was Agricultural Distress in the 1930's a Result of Land Speculation During World War I? The Case of Iowa," Annals of Iowa 40 (1971), 577-84; William G. Murray, Corporate Land, 1939, 309. Farm foreclosure statistics for the years following 1925 can be found in The Real Estate Situation, USDA circulars with numbers and years covered: no. 150 (1925-1929), no. 309 (1929-1932), no. 354 (1934), no. 548 (1934-1938), no. 662 (1937-1942), no. 721 (1943-1944), no. 754 (19451946), no. 823 (1947-1949). For commodity prices, see Gertrude M. Cox, Index of Iowa Farm Product Prices, IAES Research Bulletin 336 (1935). For land values, see William Murray, "Iowa Land Values-1803-1967," Palimpsest 48 (1967), 472-73. Iowa farm product prices, value of farmland, outstanding farm mortgage loans, and number of farm foreclosures, 1911-1940, are conveniently tabulated in Patrick B. Bauer, "Farm Mortgagor Relief Legislation During the Great Depression," Annals of Iowa 50 (1989), 24.

8. Deeds, Office of the County Recorder, Johnson County Administration Building, Iowa City. Deeds often did not include the true sale price. In an effort to conceal that information from the public, sale prices were often recorded as "One Dollar and Other Considerations." Most deeds included the cost of revenue stamps, a tax prorated according to the sale price. However, 
Fluctuating land values did not dictate the direction of change as completely as might be thought, however. Family and kinship ties have also been important in the history of land tenure. ${ }^{9}$ Evidence of family strength and inclination to retain a farmstead is manifested in Lincoln Township deed transfers between 1920 and 1950 (see table 1). Of the 154 significant deed transfers during that period, 99 were between immediate family members - fathers to sons (and less often, to daughters), siblings to siblings, and the like. Twenty-five deeds were transferred to more distant relatives or neighbors. These included members of the extended family or persons who were related through marriage. If property could not be sold within the immediate family, neighbors or more distant relatives appeared to be the next choice. With land infrequently available on the open market, property transactions generally remained the private concern of the immediate family. ${ }^{10}$

when dealing with intrafamily sales, true values were difficult to find because the sale price was often unrealistically low. Prices noted in this research were recorded prices only.

9. See, for example, Robert Diller, Farm Ownership, Tenancy, and Land Use in a Nebraska Community (Chicago, 1941); Kathleen Neils Conzen, "Peasant Pioneers, Generational Succession among German Farmers in Frontier Minnesota," in The Countryside in an Age of Capitalist Transformation, ed. Steven Hahn and Jonathan Prude (Chapel Hill, NC, 1985), 259-92; Mark Friedberger, "The Farm Family and the Inheritance Process: Evidence from the Corn Belt, 1870-1950," Agricultural History 57 (1983), 1-13; idem, Farm Families and Change in Twentieth-Century America (Lexington, KY, 1988); idem, "Handing Down the Home Place: Farm Inheritance Strategies in Iowa, 1870-1945," Annals of Iowa 47 (1984), 518-37; Kenneth H. Parsons and Eliot O. Waples, Keeping the Farm in the Family: A Study of Ownership Processes in a Low Tenancy Area of Eastern Wisconsin, Wisconsin AES Research Bulletin 157 (1945); Sonya Salamon, "Ethnic Differences in Farm Family Land Transfers," Rural Sociology 45 (1980), 290-308; Leonard Salter, Land Tenure in Process: A Study of Farm Ownership and Tenancy in a La Fayette County [Wisconsin] Township, Wisconsin AES Research Bulletin 146 (1943). These studies are only a sampling of the literature that illustrate the diversity of interests that include family farm transfers as an important aspect of their work.

10. Direct evidence describing the buying and selling of land is difficult to find. I have assumed that land sold within a family was not offered for sale on the open market. Indirect evidence that this was the case can be found in the instances when land was openly advertised for sale. These were invariably cases where no buyers could be found within the family-elderly farmers with no children or instances where a farmer died at a young age and the children were too young to operate the farm. 


\section{TABLE 1}

Significant DeEd Transfers IN Lincoln ToWNShIP, 1920-1950

\begin{tabular}{lrr}
\hline & $\mathrm{N}$ & \multicolumn{1}{c}{$\%$} \\
\hline From Parents to Children & 99 & 64.3 \\
To Distant Relatives & 3 & 1.9 \\
To Neighbor & 22 & 14.3 \\
Sold on the Open Market & 30 & 19.5 \\
$\quad$ Total & 154 & 100.0 \\
\hline
\end{tabular}

SOURCES: Deeds, Office of the County Recorder, Johnson County Administration Building, Iowa City; Manuscript Census of Iowa for 1925 (Microfilm), State Historical Society of Iowa, Iowa City; Atlas of Johnson County, Iowa, 1917; Johnson County Plat Map, 1939.

NOTE: Significant deed transfers include those transactions that actually transfered real property. Quit claim deeds or deeds serving only a technical legal purpose were generally excluded.

The intergenerational transfer of land is a critical aspect of family farm ownership. ${ }^{11}$ Most families faced several choices when making decisions concerning future ownership. They often needed to decide who would own the farm, when ownership would be passed on to the next generation, how much would be paid for the farm, what sources of funding were available, and how an equitable settlement of the estate was to be reached following the parents' deaths. Answers to these questions obviously differed from family to family depending on many variables: the amount of land, the number of potential owners, the number of siblings, ethnic differences, the wealth of the parents, and a host of intangible yet powerful factors such as interfamilial relationships, customs, community expec-

11. See Diller, Farm Ownership, 37-51, 132-39; Friedberger, "The Farm Family and the Inheritance Process," 1-13; Robert T. McMillan, "Farm Ownership Status of Parents as a Determinant of the Socioeconomic Status of Farmers," Rural Sociology 12 (1947), 151-60; Salamon, "Ethnic Differences," 293; Evon Z. Vogt, "Social Stratification in the Rural Midwest: A Structural Analysis," Rural Sociology 12 (1947), 364-75. Although his work deals with rural French society, Pierre Bourdieu effectively details the subtleties of family strategies in "Marriage Strategies as Strategies of Social Reproduction," in Family and Society, trans. Elborg Forster and Patricia M. Ranum, ed. Robert Forster and Orest Ranum (Baltimore, 1976), 117-44. Bourdieu's warning against legalistic interpretations of life and family relationships should be heeded. 
TABLE 2

Acreage Changes among Lincoln Township Farm OWNers, $1920-1940$

\begin{tabular}{lrr}
\hline Holdings in 1940 & $\begin{array}{r}\text { Number } \\
\text { of Acres }\end{array}$ & \multicolumn{1}{c}{$\%$} \\
\hline Owned by Same Owner as in 1920 & 7,006 & 45.6 \\
Owned by Son or Daughter of 1920 Owner & 4,594 & 29.9 \\
Owned by a Distant Relative of 1920 Owner & 240 & 1.6 \\
Owned by a Neighbor of a 1920 Owner & 1,322 & 8.6 \\
Owned by Person Unrelated to 1920 Owner & 2,198 & 14.3 \\
$\quad$ Total & 15,360 & 100.0 \\
\hline
\end{tabular}

SOURCES: Deeds, Office of the County Recorder, Johnson County Administration Building, Iowa City; Manuscript Census of Iowa for 1925 (Microfilm), State Historical Society of Iowa, Iowa City; Atlas of Johnson County, Iowa, 1917; Johnson County Plat Map, 1939 (Iowa City, 1939).

anly persons whose land adjoined the previous owner are included as neighbors.

bFigure includes 1200 acres transferred as the result of foreclosure.

tations, and personal desires. ${ }^{12}$ When the influence of a severe economic depression is added to this list, it seems reasonable to expect measurable changes in this process as families reacted to the uncertainties of their time.

But in many ways these changes occurred slowly. A comparison of Lincoln Township farm owners at two points in time reveals the stability of the community and the importance of familial and geographical links (see table 2). Many farmers owned their land for long periods of time, generally relinquishing ownership only as they neared retirement or death.

Yet long-term ownership of the land was seldom easy. When the number of heirs was large or the assets small, many hurdles had to be overcome to retain ownership of the farm within the family. In these situations, common among the farm owners of Lincoln Township, land was seldom parceled out prior to the parents' deaths, and the amount of cash was often

12. The best description and analysis of midwestern intergenerational transfers is found in Mark Friedberger's works cited in note nine. Although ethnic differences are not the focus of this paper, they are a logical next step. Kathleen Neils Conzen and Sonya Salamon have explored the importance of European roots in Conzen, "Peasant Pioneers," and Salamon, "Ethnic Differences." 
small. Landholdings were often insufficient to allow more than one, or in some cases two, son(s) (and infrequently daughters) to become owners. Since the land represented the bulk of the assets, parents needed to find ways to provide equitable divisions of their assets and yet maintain ownership within the family. The experience of one Lincoln Township farmer illustrates this process.

When Charles Cerny, Sr., died in July 1930, he owned 160 acres of farmland in Lincoln Township. His will stipulated that 80 acres be given to each of his two sons, while his wife, his three daughters, the wife of his deceased son, and two of his grandchildren were to receive cash. However, at the time of his death, Charles Cerny lacked sufficient cash to make an equitable settlement, a situation he anticipated in writing his will. His solution was for each of the two sons to pay $\$ 3,850$ to the estate for their land. At $\$ 48$ per acre, the cost represented a substantial discount in comparison to the $\$ 200$ per acre paid by Cerny's son William for eighty acres he purchased from a neighbor earlier in the year. Cerny also specified that the money received from his sons be divided among the remaining heirs in amounts ranging from $\$ 101$ for his daughter-in-law to $\$ 4,368$ for his wife. Even if the land were appraised at only $\$ 100$ per acre, the sons' share of the inheritance was more than $\$ 4,000$, twice that of any of their sisters. Clearly, Charles Cerny's treatment of his children was inequitable, but he was successful in ensuring that the family retained the land. ${ }^{13}$

Another family's experience illustrates the careful planning that was often required to retain the family's land. In 1927 Michael Schuessler, then over seventy-five years old, divided the bulk of his farmland among three sons. Borrowing money from three different aunts, the sons paid for their land and began farming on their own. The transaction obviously involved extensive prior negotiation because the deeds were transferred and the notes were signed on the same day. ${ }^{14}$ By uti-

13. Probate Docket 5192, Clerk of Court, Johnson County Courthouse, Iowa City.

14. Mortgage Record, book 76, pp. 283-84, Office of the County Recorder, Johnson County Administration Building, Iowa City. 
lizing the family networks, the sons secured the necessary capital on reasonable terms and may have felt less vulnerable dealing with their aunts than with a bank or mortgage company. Through careful planning, Schuessler placed all of his sons in positions of ownership, something most farm families were unable to achieve during this period.

Yet the Cerny and Schuessler families were not alone in successfully retaining ownership of the land within the family: more than three-fourths of the farm families in Lincoln Township managed to hold on to their land from 1920 to 1950. Their experiences encompassed a broad middle range that contrasts with the extremes of increasing wealth and financial collapse found at the top and bottom of the economic hierarchy. Unlike the few families whose assets placed them beyond the threat of the depression or those families who lost their land through foreclosure, this broad "middle class" of "survivors" felt the threat of a collapsing economy but managed to retain possession of their property. Because these "survivors" represented the bulk of the farm-owning population, the strategies they employed to persist on the land deserve attention.

Each of the steps in the transfer process involved risk and difficulty. The problems encountered in that process during the depression threatened almost any family without substantial cash reserves. In retrospect, most were never in immediate danger of losing their land, but they could not ignore the threat posed by the depression. Among survivor families, interesting patterns of property transfer emerged to help ensure a successful transition to the next generation in the midst of economic depression.

CHANGES in transfer patterns among survivor families occurred on several different levels. First was a change simply in the frequency of deed transfers. Land was not sold at a consistent rate throughout the period. A second change took place in the handling of property as it passed into probate following the deaths of the parents. It was a change not only in the amount of land but also in the length of time property 
FIGURE 1

DeEd Transfers WITHIN THE SuRvivor CATEgory

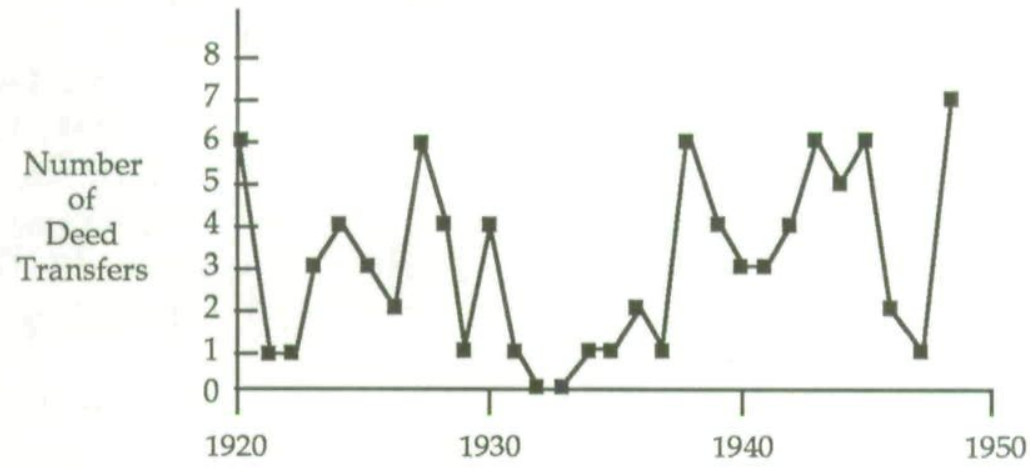

SourCE: Deeds, Office of the County Recorder, Johnson County Administration Building, Iowa City.

remained either in probate or in common ownership of the children. ${ }^{15}$

Patterns in the number of transfers per year within the survivor group reflect some of the fluctuation inherent in a small sample. However, the decline in the number of transfers, first in the early 1920 s and then after 1930, seem more pronounced than one might expect from random fluctuations (see fig. 1). While thirty-six transfers occurred from 1920 to 1930, only six took place in the following seven years; and in 1932 and 1933 there were no transfers at all. Of the twenty transfers in the decade of the thirties, half occurred after 1937. In the following decade, there were forty-one transfers.

Fear that the risks of farm ownership were too high may account for the pronounced decline in the number of transfers during the depression years. Most parents lacked the means simply to give farms or cash to their children, so the farmers in

15. Leonard Salter found a similar situation in his survey of a Wisconsin township in Land Tenure in Process, 38. Also see Friedberger, Farm Families and Change, 56. 
the next generation almost always paid something for the land. To be sure, the price and terms were often very favorable for the buyer, but if the parents made any attempt to be equitable in the treatment of their children, the amount could still be substantial. If the purchaser borrowed money from an outside lender and was unable to repay the loan, the farm could be lost to an outsider. The loss of the farm could mean the loss of most of the assets of both the parents and the son. Parents often saw the farm as a source of security in their old age and depended on the money generated from rental income or from the sale of the land.

Sales prior to 1940 generally involved a transfer of the deed at the time of the sale, an action that had serious legal implications. ${ }^{16}$ In the 1930 s parents must have been reluctant to convey a deed when it carried with it the possibility of losing the farm should the son prove unable to meet his obligations. In the midst of a depression, even a responsible and capable son faced a huge obstacle by assuming ownership. For parents, the best alternative in a difficult situation was to delay the transfer and not jeopardize the ownership of the land unless absolutely necessary.

16. Land sales generally involved one of two options: either cash was paid for the land or a down payment was made and the deed transferred to the buyer with the seller retaining a first mortgage on the unpaid balance. This latter method was apparently discontinued after 1940 when contract sales became more popular. In a contract sale, the seller retains possession of the deed until the full balance has been paid. The buyer is given most of the privileges of ownership but has no deed. The difference between the two systems can have important legal ramifications when the buyer is unable to fulfill his or her obligations, particularly when a second mortgage is involved. For the purposes of this article, it is necessary only to realize that transferring the deed immediately places the seller at more risk in the event of foreclosure by a second mortgage holder than does a sale where the deed is not transferred until the contract is paid in full. In the first instance, the seller loses a greater degree of control over the management of debts against that particular property and is more likely to suffer financial loss if the property is involved in litigation over unpaid debts. Sellers, unwilling to risk their farms because of actions by buyers who were beyond their control, may have turned to contract sales as a more secure alternative. Other considerations, such as changing tax implications, might have also been factors. William Murray briefly addresses these changes in Corporate Land, 325-27, as does Mark Friedberger in Farm Families and Change, 55. 
An example of how this process may have worked can be found in the case of the Peter and Ella Lenz family. When Peter Lenz died intestate in 1920, his heirs received an undivided interest in the two hundred acres he owned in Lincoln Township. Ella Lenz acquired one-third of the property, while the three children-Freda, Elsie and Vernon-inherited the remaining two-thirds. ${ }^{17}$

Because sons traditionally succeeded their fathers as farm owners and because Peter Lenz died prematurely, we might have expected Vernon Lenz to begin purchasing the family farm soon after he turned twenty-one in 1928. Yet it was not until February 1943 that Vernon Lenz, then thirty-five years old, purchased the undivided interest of his mother and his sisters. ${ }^{18}$ By then the depression was clearly over and the farm economy was expanding as the demand for food grew during the Second World War. Profitability in farming and rising land values may have lessened concerns about transferring ownership, giving Vernon Lenz the confidence to purchase the land.

Delays of a few years in settling individual cases may not be convincing proof of overall changes. Families left no documents stating their intentions to delay farm ownership transfers. However, the common thread that explains the pattern of delays in property transfer is the depression and the threat it posed to that process.

With parents maintaining ownership of their farms longer, increasing amounts of land entered into probate upon the deaths of the owners. The number of acres held in either unsettled or undivided estates rose dramatically following 1929. Prior to that time, property usually remained in an estate for less than one year and then passed to a new owner, usually one or more of the sons. Since the largest portion of the parent's assets normally was land, farming heirs generally purchased the shares of the farm owned by their siblings, consolidating farm ownership into one or two hands.

Prior to 1927, the time required to settle an estate was generally less than two years, and an average of one to three new

17. Probate Docket 3493.

18. Deed, book 161, p. 435. 
FIGURE 2

ACRES HeLd IN UNSETTLED OR UNDIVIDED EsTATES

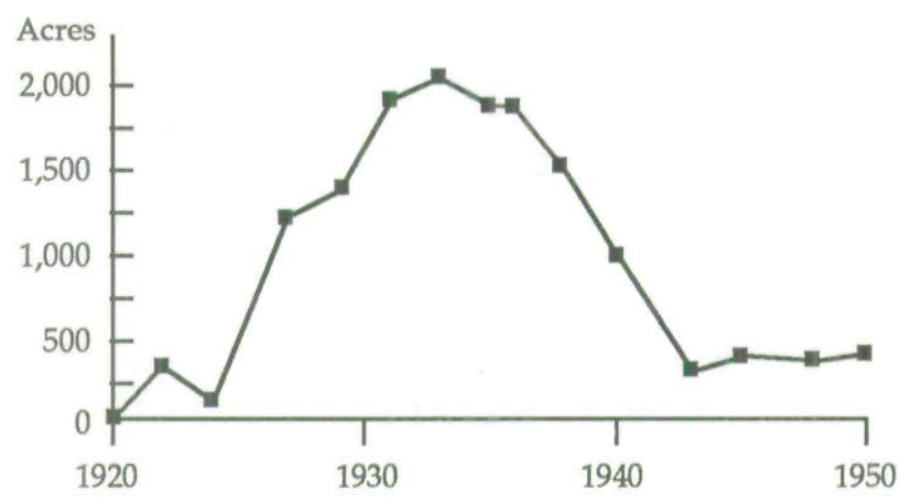

SOURCE: Tax schedules, property tax lists, 1920-1950, County Treasurer; Deeds, Office of the County Recorder, Johnson County Administration Building, Iowa City; Township Assessor Ledgers, 1926-1933, Lincoln Township Clerk, Iowa City.

estates were formed in any given year. The number of acres held by estates was never more than 317 in any one year, and in 1920 no land was held by an estate (see fig. 2). However, by 1929 a total of 1,400 acres was held either by estates or in common ownership of the heirs. The figure reached a peak of 2,077 acres in 1933. The length of time required to settle an estate or divide and then consolidate the ownership of the farm also increased substantially. From 1931 to 1939 at least eight separate farms were always being held in such a manner, and in one year, 1932, there were fourteen farms in unsettled estates or in common ownership of the children. Instead of being settled expeditiously following the death of the last surviving parent, estates were maintained longer and the length of time required to place ownership of the land in the hands of the farmer of the next generation increased substantially. ${ }^{19}$ Estate settlement and consolidation of land ownership increased after 1939. By 1943

19. Unlike today, when estates need to be settled and closed within one year of inception, no rules existed limiting the length of time estates could remain open. 
the number of acres held in unsettled or undivided estates had fallen to 320 , and the number of estates was down to three.

Among those who illustrate this pattern of behavior was the Prizler family, who owned property in western Lincoln Township. Peter Prizler's wife Mary and his three children faced difficult circumstances during the depression-circumstances shaped by his death in 1926 and by the subsequent economics of low prices, dwindling profits, and rising debt.

Peter Prizler was not a wealthy man. His assets at the time of his death in 1920 included 120 acres of land, a house in Iowa City, and \$1,400 in cash and savings. ${ }^{20}$ Following his death, his property was held jointly by his wife Mary and their three children. George and Ella Frus, Peter and Mary Prizler's daughter and son-in-law, who had been renting the farm, continued on as tenants. Rental income from the farm paid Mary Prizier's living expenses and the installments on the house. Although her wealth was not abundant, there appeared to be no reason for great concern over Mary Prizler's finances in 1926. If farming continued to be profitable during the next decade, she could look forward to a fairly comfortable retirement-not lavish, but adequate.

In May 1931 the Prizlers mortgaged the 120 -acre farm and borrowed \$4,500 from two lenders-the Johnson County Savings Bank and a private individual, James Meade. ${ }^{21}$ In addition to the mortgage, George Frus's declining assets were a second indication of increasing difficulty. In 1920 Frus showed no taxable assets, but by 1929 he had accumulated property and cash with an assessed value of $\$ 2,376$. Only four years later, in 1933 , during the depths of the depression, his assets were valued at only $\$ 928$, none of which was cash. ${ }^{22}$

At this point, the Prizlers obviously were experiencing the effects of the depression. The first mortgage on their land in forty years and the declining fortunes of George and Ella Frus must have caused deep concern about the future. A mortgage

20. Probate Docket 4389.

21. Mortgage Record, book 82, p. 317.

22. Property Tax Ledgers, Johnson County Courthouse, Iowa City. 
of thirty dollars per acre may not seem significant, but to persons like Mary Prizler, now an elderly widow, or to George and Ella Frus, who may have had aspirations of buying the farm, the future was no doubt viewed with apprehension. The closing of many banks between 1930 and 1933 and instances of foreclosure involving friends and neighbors could cause even a relatively small mortgage to appear vulnerable.

Whether the Fruses decided not to buy the farm as a result of the depression is speculation. The farm was always owned jointly by the children and Mary Prizler. In 1964, long after Mary Prizler had died, the children sold the property. George Frus farmed in Lincoln Township until 1947, when he moved to Iowa City. ${ }^{23}$ It seems possible, even likely, that the depression may well have influenced his choice among the alternatives available to him, causing him to question the wisdom of assuming the responsibility and risk of ownership.

In the case of the Prizlers and many others, property accumulated in unsettled estates and in a shared ownership because the more normal processes had been interrupted. It is not immediately clear, however, why families chose this option (or allowed it to happen). Other options were certainly available. For instance, land could always be sold on the open market and the money from the sale divided among the heirs. Yet this happened infrequently, evidence that families were deliberately protecting the ownership of the land.

One reason for the changes in transfer patterns might have been a growing reluctance on the part of potential owners to assume ownership of the farm. William Murray, an agricultural economist, noted in 1935, "It is a sad commentary on our farm civilization that the majority of land sales take place in years of high land prices and few sales in years of low land prices." 24 Falling land prices bring doubt and uncertainty, making buyers reluctant to enter the market after experiencing the volatility of

23. Edith Schuessler, Alta Lenz, and Jessie Lenz, Pioneer Families and Their Descendants in Fremont, Lincoln and Pleasant Valley Townships Area, Johnson County, Iowa, 1837-1900 (Marceline, MO, 1979), 404.

24. William G. Murray and Willard O. Brown, Farm Land and Debt Situation in Iowa, 1935, IAES Research Bulletin 328 (1935), 23. 
the price swings. Even less tangible but nonetheless powerful aspirations to own "the home place" may have been squelched by the devastating decline in both commodity and land prices.

When no distribution of assets had taken place prior to the parents' deaths, the children sometimes faced difficult choices. If the heirs agreed that the farm should remain in the hands of a sibling and if cash was in short supply, it was necessary to devise a method by which all the demands could be met as adequately as possible. ${ }^{25}$ One solution was to own the farm "in common" rather than force the farming heir(s) to buy the nonfarming shares - a situation that would have made it difficult, if not impossible, for many farming heirs to survive. Even if the heirs had no strong inclinations to retain family ownership, this method was much more attractive than selling the farm on the open market and dividing the cash. With land prices low, many people felt the prices of land in the mid-1930s represented a bargain for the purchaser. It is very likely that nonfarming heirs anticipated the rebound in land values and the corresponding increase in their share of the inheritance.

The handling of any estate can be a sensitive matter and may be influenced by a host of factors, including sibling rivalries, differing needs of the heirs, and the assumed but intangible and no doubt varying desire to keep the land within the family. Survivor families in Lincoln Township reacted to economic uncertainty by delaying the transfer of ownership into the hands of a few siblings and thus did not threaten the inheritance and the integrity of the "home place."

The success of the survivors' strategies is reflected in the foreclosure rates in Lincoln Township, which remained low throughout the thirty-year period. No foreclosures occurred between 1920 and 1930 or between 1940 and 1950. Even during the 1930s, foreclosures averaged less than one per year. Ninety-four percent of Lincoln Township's farm families escaped foreclosure altogether, although some appeared to flirt with foreclosure when they extended mortgages or failed to

25. Inheritances were always partible except in the case of three life estates that were formed after 1940 . Property was divided and in no cases were farms given intact to only one child when other siblings were involved. 
meet property tax deadlines. Some of the survivors even managed to expand their holdings, but only with great caution. In the legal documents generated during this period, then, the stability and persistence of the community's farmers is more evident than the dramatic economic or social shifts usually associated with the depression and its aftermath.

UNDERLYING these apparently stable conditions in the township, however, were hidden disparities. The number of farm owners remained unchanged, but a comparison of owners in 1950 with those in 1920 shows distinct and unequal patterns of gain and loss. In addition to the large group of farm families I have called survivors, there were two other sharply contrasting sets of farm families: "disadvantaged" farmers, who lost their farms, and "gainers," who added significantly to their landholdings between 1920 and $1950 .{ }^{26}$

Six of the 1920 farm owners eventually lost their land through foreclosure. Several of these "disadvantaged" farmers owned large amounts of land and held substantial assets in 1920, but a variety of factors - falling land and commodity prices, large mortgages, poor crop years, and other less tangible factors-eroded their financial bases. As their net worth approached or fell below zero, foreclosure became unavoidable. Not all of these disadvantaged farmers left the community during the period, but they did lose their land.

At the opposite end of the spectrum of depression experiences were seventeen farmers-"gainers"-whose assets in 1920 were also substantial. Representing five extended families, these persons always owned large amounts of land and cash and never mortgaged their property during the subsequent thirty years. They not only survived the depression; they

26. The justification for the three-part classification scheme is rather simple. Not intended to be a predictive or sophisticated analytical tool, the categories allow one to see how families with varying resources reacted to the depression. These categories are heuristic and not the result of a detailed statistical manipulation of the data. However, the five gainer families clearly stood apart in terms of wealth while the families who lost their land obviously shared an important identifying experience. Data were collected from tax ledgers, mortgage record books, and deed books. 
actually expanded their holdings significantly by purchasing relatively cheap land. Operating beyond the constraints of low prices and falling property values in a way other families could not, persons in this group transferred property to their children without serious concerns about financial failure. For the gainers, the depression was a time of opportunity.

By contrast, the disadvantaged families were totally constrained by their financial plight. In almost all cases, they had little choice in matters of property transfer because they no longer controlled the ownership processes as their land passed into the hands of receivers. Thus, for very different reasons, ownership decisions in these two categories reflected different patterns than those of survivor families who felt the threat, either real or psychological, of the depression, and made choices to deal with the threat.

For gainers and the disadvantaged, the depression was a time of expansion and loss. Even though several of the six disadvantaged families had a substantial net worth in 1920, they all experienced sporadic decline after 1920 and pronounced, sharp decline after 1930. Borrowing increasing amounts of capital against declining asset bases, these families eventually lost their land through foreclosure. For the gainers, falling land prices and foreclosures brought land onto a cash-starved market. It was their opportunity for expansion. The experiences linking two farmers in northern Lincoln Township well illustrate the extremes.

Born in 1878, Carl Paulus first acquired property in section four of Lincoln Township in December 1909, buying 244 acres from the estate of his father-in-law, Edward Whitacre. He paid $\$ 30,500$, or $\$ 125$ per acre, for the farm. On March 4, 1918, Paulus bought an adjoining 160 acres from Charles Bell for $\$ 41,500$, or almost $\$ 260$ per acre. He paid $\$ 15,000$ down, and the remaining $\$ 26,500$ was placed on a five-year note with Bell. At this point, Paulus owned a total of 404 acres, making his the second-largest landholding in the township. ${ }^{27}$

Paulus fed Shorthorn cattle on a large scale; his name appeared frequently on the list of community farmers who

27. Deed, book 95, p. 377 , and book 120 , p. 338 . 
shipped cattle to Chicago. For example, in July 1920, at a time when most farmers had fewer than ten head of cattle on feed, he shipped five carloads, or approximately 175 head of cattle. ${ }^{28}$ Paulus bought yearling feeder cattle and fattened them to market weight, a strategy that required substantial amounts of capital and carried the highest risk of virtually any livestock operation. ${ }^{29}$ The possibility of wide price swings between the time the cattle were purchased and the time they were sold meant the potential existed for large profits or large losses. Also, because a steer weighed over one thousand pounds at market weight, the loss of one or two animals to disease or injury could mean the difference between a profit and a loss.

Paulus borrowed large sums of money, presumably to finance his cattle operation. In 1921 he borrowed \$24,000 from the Bankers Life Insurance Company, mortgaging the 160 acres he had purchased from Bell in 1918. He apparently used some of this money to pay the balance of his obligations to Bell because the property was released and assigned to the insurance company as collateral for their loan. In 1924 Paulus refinanced this note and borrowed additional amounts. In June he borrowed \$15,000 from the Johnson County Savings Bank, giving them a second mortgage on the 160 acres purchased from Bell. On August 1, 1924, Paulus borrowed a total of $\$ 40,000$ in three separate notes with the Collins Mortgage Company, mortgaging the entire 404 acres. The loan with the Bankers Life Company was released and apparently paid, probably with money from the new loan. Paulus now had debts of at least $\$ 55,000$, or $\$ 137$ per acre of land, a sum which may have seemed reasonable when land was selling for $\$ 300$ per

28. Lone Tree Reporter, 21 July 1920.

29. Township Assessor Ledgers, 1923-1933, Lincoln Township Clerk, Iowa City. A study by William G. Brown and Earl O. Heady, Economic Instability and Choices Involving Income and Risk in Livestock and Poultry Production, IAES Research Bulletin 431 (1955), 548-68, found that of the ten production enterprises compared, returns for feeding yearling or two-year-old cattle produced the highest year-to-year fluctuations. The average fluctuation of capital return as a percentage of the mean for yearlings and two-year-olds was 166.40 but did not exceed 100 for any other non-cattle enterprises (557). 
acre, but was becoming unmanageable as prices for commodities and land fell. ${ }^{30}$

No records concerning Carl Paulus appeared again until the loans were foreclosed on February 15, 1934. The entire farm was sold by the Johnson County sheriff on March 20, 1934 , for a sum of $\$ 45,685$, or $\$ 113$ per acre, to the Equitable Life Assurance Society, underwriter for the now defunct Collins Mortgage Company, the holder of the first mortgage. Equitable purchased the property to protect their investment, hoping to sell it later at a more favorable price. Had they allowed the farm to be sold, it is likely the price would have been well under $\$ 100$ per acre. Carl Paulus never saw the sale of his farm. Tragically, and somewhat ironically, he died on October 28, 1933, in a corn-picker accident at the far end of the 160 -acre farm that was the cause of so much difficulty. ${ }^{31}$

Probate records indicate that Paulus had accumulated additional, unrecorded debt in the years between 1924 and 1933. Borrowing from individuals, his liabilities totaled $\$ 50,000$ in addition to the debt with the Johnson County Savings Bank (then in receivership) as well as debt for an undisclosed amount with the First Capitol National Bank and W. C. Walden. The sale of the farm machinery and 126 young heifers and the proceeds from Paulus's life insurance policy were applied to those debts. Any money available to Martha Paulus would have come from funds remaining from the insurance policy; all other assets were sold or in foreclosure. ${ }^{32}$

The experience of the Paulus family reflected one of the most extreme situations in Lincoln Township. In fifteen years they had gone from a solid financial position to total collapse. What must have seemed like a good business decision in 1918, when Carl Paulus paid Charles Bell more than $\$ 40,000$ for 160 acres of land, eventually spelled the end for the Paulus family as landowners.

30. Mortgage Record, book 52, p. 46, book 74, p. 144, book 64, pp. 592-94. 31. Sheriff's Deed, book 165, pp. 122-24, Office of the County Recorder, Johnson County Administration Building, Iowa City; Lone Tree Reporter, 2 November 1933.

32. Probate Docket 5765. 
Sales by receivers of land broke the normal cycle of intrafamily sales and placed land on the open market to be sold to the highest bidder. Paulus's land would not be sold to a relative, and the Equitable Life Assurance Company was not interested in owning land. ${ }^{33}$ Their search for a buyer provided an opportunity for Ed Hotz, a neighboring farmer, to expand his own landholdings. In May 1938, four years after the foreclosure of the Paulus farm, Hotz bought the entire 404 acres from the Equitable Life Assurance Society for $\$ 47,500 .{ }^{34}$ Paying less than $\$ 120$ per acre for prime farmland, Hotz made an extremely profitable purchase, given the upward movement of land prices during the 1940 s.

In contrast to Carl Paulus, Ed Hotz was apparently able to finance both his land purchases and cattle operations without borrowing any money. At no time did he appear to risk either his land, personal property, or livestock in order to expand. A cattle feeder, Hotz consistently maintained cattle numbers of 100 or more and, in 1933, had more than 210 cattle on feed. ${ }^{35}$ His ability to feed cattle throughout some of the least profitable years in agriculture and still earn a profit indicates he must have possessed good management and marketing skills. In 1931, when most farmers were facing a severe cash shortage, Ed Hotz paid personal property tax on cash assets of $\$ 22,000 .^{36}$

33. The actions of corporations following the years with high numbers of foreclosures in the mid-thirties suggest that they did not attempt to reap speculative profits from rising land values. According to John F. Timmons and Raleigh Barlowe, Farm Ownership in the Midwest, Iowa AES Research Bulletin 361 (1949), 857, corporate ownership of farmland fell from a high of 12.9 percent in 1939 to 1.9 percent in 1945 . Evidence in William Murray's Corporate Land shows that corporations, and especially insurance companies, used contract sales with low down payments to dispose of their land. Had they been interested in speculative profits, it would have been more advantageous for corporations either not to sell property or to sell it at terms more favorable for the seller.

34. Deed, book 164, p. 281.

35. Township Assessor Ledgers, 1923-1933.

36. Tax schedules and property tax lists, 1920-1950, County Treasurer, Johnson County Administration Building, Iowa City. Assessments were made biannually and did not reflect the amount of cash that may have flowed into and out of a particular operation during the intervening time. Assessors, as instructed in the 1933 Iowa Assessors Manual, could not examine the books of a bank or corporation "for any purpose" (p. 78). Local assess- 
Ed Hotz enjoyed several advantages not available to everyone. Obviously he was a shrewd manager, willing to take risks, but risks he could afford. He was a patient man, able to wait until the optimum time to make a purchase and also able to recognize when that moment had arrived. Part of his success might be attributed to luck, but luck does not adequately explain the growth of his operation through some of the least profitable years in American agriculture.

Having his own operating capital instead of borrowing money played an important role, not only because of the savings in interest payments, but also because it gave him freedom to undertake higher risk ventures, knowing that a mistake would not be devastating. Because Hotz was never in a position where he absolutely had to turn a profit or be faced with bankruptcy, short-term losses were not catastrophic.

By using his sons to farm his ground instead of leasing it to tenants, Hotz undoubtedly increased his net income. Assessor records and conversations with persons who knew Ed Hotz show that he rarely hired long-term outside help. ${ }^{37}$ Not renting his land to tenants allowed him to manage his entire crop production. Considering the amount of livestock he owned, corn and hay would have been more valuable to him than the five or six dollars per acre he might have received by leasing the land.

As cattle-feeders, Paulus and Hotz shared a characteristic common to families who failed and those who expanded. All but one of the families who failed fed large numbers of cattle,

ors relied only on information provided by the individual being assessed. Infrequent audits did occur; the three that took place in Lincoln Township between 1920 and 1950 found additional cash assets of almost fifty thousand dollars.

37. Assessor records provided detailed information about the age and number of horses on each farm. According to those records, Ed Hotz owned twelve horses. Throughout this period, the ratio of draft horses per acre of land averaged 1:35 in Lincoln Township. This ratio was remarkably consistent both throughout the early part of the study period and from farm to farm. Thus, for example, a farmer with eighty acres of land would be expected to have at least two and sometimes three horses, and one with 160 acres would have four and sometimes five. Since tenant farmers provided their own horses, Ed Hotz had no apparent reason to own twelve horses unless he was farming all of his 240 acres himself. 
indicating the risk involved in the undertaking. That four of the most prosperous families likewise fed cattle indicates its corresponding potential for profit.

The difference between failure and prosperity is most likely linked to differences in management skills and the use of borrowed capital as opposed to having available capital to finance one's operations. Management skills cannot be easily discerned, but the differences in funding techniques are readily identified. The most successful families never mortgaged land, while those who failed mortgaged property frequently. Some families in the survivor group mortgaged property but were more conservative and their debt-per-acre remained consistently lower. For instance, during the years from 1923 to 1925, a time when many of the disadvantaged families could still borrow without apparent restraint, five of them took out loans totaling $\$ 136,800$. That contrasts with seven mortgages filed in the survivor group for a total of $\$ 45,629.38$

Essential ingredients for perpetuating ownership through the next generation-sufficient land and capital and a resolve to retain property within the family-were not always in abundance. Families who struggled the most were deficient in one or more of these areas. The Prizlers, for example, lacked not only the capital but also sufficient land to successfully withstand the effects of the depression. One hundred and twenty acres did not provide an adequate income base for the Fruses as renters and for Mary Prizler in her retirement to allow them to overcome the financial pressures of the 1930s.

A COMPARISON of the experiences of the Prizler, Paulus, and Hotz families reveals several clear differences. The lack of available capital was central to Paulus's demise, just as its availability was crucial to Hotz's expansion. With the Prizlers, the lack of cash was not disastrous, but the effects of too little cash were painfully evident as the family struggled during difficult times. The Prizlers survived, but they were slowly losing their hold on the land. It is their story, far less dramatic than that of

38. Mortgage Records. 
Carl Paulus or Ed Hotz, that is perhaps closer to the larger truth of Lincoln Township.

Of the 104 property owners in Lincoln Township in 1920, 81 were persons earlier termed "survivors" - persons who were able to keep their farming operations intact, and in some cases successfully transfer ownership to a son or sons. Seventeen property owners in 1920 were persons whose operations grew significantly in spite of the harsh economic times. Six persons who owned land in 1920 lost their farms by 1939, most of them permanently. In 1920 those whose operations were to grow during the next three decades held 4,109 acres of land, while those who eventually lost their farms held 1,135 acres of land. The 81 survivors held 10,236 acres of land. Of those in the survivor category, 57 owned farms ranging in size from 80 to 160 acres, a range reflecting the number of acres necessary to sustain a family. ${ }^{39}$

Thirty years later, the total number of landowners remained unchanged. Seventy-four of the 104 had survived, owning a total of 9,361 acres. Twenty-eight owners in 1950 were members of families whose fortunes had improved and who now held 5,519 acres. One of the original disadvantaged owners had retrieved his farm after foreclosure proceedings. He had, in fact, done quite well; by 1950 he owned 320 acres of land. In another instance of foreclosure, the son of a man whose farm had been seized by the sheriff purchased the farm. These two persons owned a total of 480 acres. Gaining families were able to increase their total holdings by 31 percent, while surviving families lost 7 percent of their total holdings and disadvantaged families lost more than 57 percent of their holdings. Although families in the survivor category did not suffer foreclosure, they experienced a significant erosion of their economic position (see table 3 ).

39. Plat maps, unavailable for most of the years studied, were reconstructed for each year from deed records and subsequent deed transfers and then reconciled with property tax records to ensure proper accounting of all property in the township. 
TABLE 3

COMPARATIVE HOLDINGS OF LINCOLN TOWNSHIP FARMERS BY GROUP IN 1920 AND 1950

\begin{tabular}{|c|c|c|c|c|c|c|c|c|}
\hline \multirow[b]{2}{*}{ Category } & \multicolumn{4}{|c|}{1920} & \multicolumn{4}{|c|}{1950} \\
\hline & $\begin{array}{l}\text { Number } \\
\text { of } \\
\text { Farmers }\end{array}$ & $\%$ & $\begin{array}{l}\text { Acres } \\
\text { Owned }\end{array}$ & $\%$ & $\begin{array}{c}\text { Number } \\
\text { of } \\
\text { Farmers }\end{array}$ & $\%$ & $\begin{array}{c}\text { Acres } \\
\text { Owned }\end{array}$ & $\%$ \\
\hline Survivors & 81 & 77.9 & 10,116 & 65.9 & 74 & 71.2 & 9,361 & 60.9 \\
\hline Gainers & 17 & 16.3 & 4,109 & 26. & 28 & 26.9 & 5,519 & 36.0 \\
\hline Disadvantaged & 6 & 5.8 & 1,135 & 7.4 & 2 & 1.9 & 480 & 3.1 \\
\hline Total & 104 & 100.0 & 15,360 & 100.0 & 104 & 100.0 & 15,360 & 100.0 \\
\hline
\end{tabular}

SOURCE: Deeds, Office of the County Recorder, Johnson County Administration Building, Iowa City.

Perhaps more important in these figures is evidence that gainers were much more successful in integrating sons into their farming operations. Given their resources, this should not be particularly surprising. During the first twenty years, four of the gainer family heads divided property among their children. In one case, two brothers divided property among six sons, leaving each son with an average of 282 acres while one of the fathers still held 320 acres. By 1950, gainers, a group that numbered 17 household heads in 1920, had brought 22 sons or grandsons into positions of ownership. By comparison, the group of survivors- 81 in 1920 -brought 39 sons into ownership positions over the thirty years. Gainers placed a far higher proportion of sons in ownership positions than did survivors. The easing of the financial difficulties during the decade of the forties had an effect on the willingness among the survivors to transfer property. Of the 39 sons brought into positions of ownership by 1950, 23 were integrated after 1940.

One could argue that family ownership was logical simply because it was the sons who acquired the knowledge and skills necessary to operate a farm. While it is true sons may have had an advantage over persons who lacked those skills, another group of persons who lived in Lincoln Township demonstrated the ability to operate farms but never became owners. Throughout the thirty-year period, tenants in Lincoln Township leased farmland from off-farm owners or from farm owners having more land than they themselves could farm. Unre- 
lated to established land-owning families were a group of approximately twenty tenants, some of whom remained in the community for several years while others were more transient. Yet from this group, only one became an owner during this period. It might be expected that foreclosures would have created opportunities for tenants to assume ownership of property. Rather, it was the families in strong positions of ownership who filled those gaps and not tenants. Tenancy was not a point on the road to farm ownership for persons lacking family ties to the community. ${ }^{40}$ Kinship was as important for an aspiring owner as was farming skill and knowledge.

When the farms within a community are stable, opportunities to buy farms are limited. When the stability of a community is disrupted because of economic depression, and growth is slowed, halted, or reversed, the threads of continuity that cross generational lines sever at the most fragile points. For most families, this point is the passing of land on to the next generation. While Lincoln Township withstood the depression well in comparison to many communities, the image of stability is falsely enhanced because strong community families purchased much of the land lost through foreclosure and financial stress, enabling them to place a disproportionately high number of sons in positions of stable ownership.

THE CONCLUSIONS reached in this study reveal the varieties of depression experiences found in one small community. They suggest that the broader narrative histories of political

40. The role of tenancy in economic mobility for farmers is a matter of longstanding debate among agricultural historians, a debate that is summarized in Donald L. Winters, "Agricultural Tenancy in the Nineteenth-Century Middle West: The Historiographical Debate," Indiana Magazine of History 29 (1982), 128-53. My findings in Lincoln Township in the twentieth century contrast markedly with Winters's findings in twelve Iowa counties in the nineteenth century. Also contrast Donald L. Winters, Farmers without Farms: Agricultural Tenancy in Nineteenth-Century Iowa (Westport, CT, 1978), and Seddie Cogswell, Jr., Tenure, Nativity, and Age as Factors in Iowa Agriculture (Ames, 1975), with LaWanda F. Cox, "Tenancy in the United States, 18651900: A Consideration of the Validity of the Agricultural Ladder Hypothesis," Agricultural History 18 (1944), 97-105, and Paul W. Gates, Landlords and Tenants on the Prairie Frontier: Studies in American Land Policy (Ithaca, NY, 1973). 
and institutional changes overlook a dynamic of change operating at the local level. In many respects, the actions of the Lincoln Township farm families had far less to do with New Deal policies than with a deep desire to retain ownership of their land.

Histories stressing the dramatic farm protests that marked the depression have focused attention on events that may have been very important but were ultimately rather isolated. The long-term effect of such protests is questionable. While they may have gotten quick response and, in some cases, may have saved individual farms, the possibility of manipulation by mobs and by individuals whose actions bordered on demagoguery dims the populist halo worn by the farmer protesters.

In contrast to the events of protest and government intervention, local farm life, as experienced by Lincoln Township families, takes on a quiescent air that belies the significance of the efforts they made to stay on the farm. Ultimately those efforts illustrate the importance of the facets of life that often appear mundane, unimportant, and unchanging. In the face of an economic depression they could do little to avert, families fought back quietly, using familiar resources. Some did not win the fight, and others fought to a draw. For most, it was a struggle they outlasted. 
Copyright of Annals of Iowa is the property of State of Iowa, by \& through the State Historical Society of Iowa and its content may not be copied or emailed to multiple sites or posted to a listserv without the copyright holder's express written permission. However, users may print, download, or email articles for individual use. 